\title{
ENCARCERADAS: OS DESAFIOS DE SER MULHER NO SISTEMA CARCERÁRIO BRASILEIRO
}

\section{INCARCERATED: THE CHALLENGES OF BEING A WOMAN IN THE BRAZILIAN PRISON SYSTEM}

SOARES, BEATRIZ SOUZA BATISTA

Graduanda do curso de Direito, na modalidade Integral, Escola Superior Dom Helder Câmara - Belo Horizonte - MG. E-mail : beatrizsbsoares13@gmail.com

CAIO AUGUSTO SOUZA LARA Mestre e Doutor em Direito pela Faculdade de Direito da Universidade Federal de Minas Gerais - UFMG. Professor da Escola Superior Dom Helder Câmara. Pesquisador associado ao Programa RECAJ-UFMG - Acesso à Justiça e Solução de Conflitos. Secretário de Comunicação do Conselho Nacional de Pesquisa e Pósgraduação em Direito - CONPEDI. Belo Horizonte- MG. E-mail: caiolarabh@yahoo.com.br.

\section{RESUMO}

O tema-problema da pesquisa que se pretende desenvolver é a desigualdade, invisibilidade e constate violação dos direitos fundamentais das mulheres no sistema carcerário brasileiro. A reflexão acerca do tema inicia a partir da análise do caos instaurado nas penitenciárias femininas ao longo de todo território brasileiro e do que o Estado prevê como garantias para o seu povo. Em primeiro plano, pode-se afirmar, que essas infrações ocorrem, levando em conta que achar fezes de rato na comida ou pegar uma micose extensa da genitália até o meio da coxa, e não conseguir trata- 


\section{Personalidade Acadêmica Homenageada:}

Augustus B. Cochran III (Agnes Scott College)

la pela junção da proliferação de micróbios nas celas e falta de produto de higiene pessoal não conferem com a garantia constitucional de não submissão a tortura, nem ao tratamento desumano ou degradante. $\mathrm{O}$ abandono sofrido pelas presidiárias, destacando seus familiares, é essencialmente gerado pela instaurada sociedade patriarcal que não reconhece como iguais homens e mulheres, especialmente em situação de cárcere. Diferente da maioria da população masculina, as mães, avós e principalmente namoradas ou esposas dos presos não costumam abandonar seus cônjuges. Muitos casos de depressão se iniciam com esse desamparo, e se estendem por tempo prolongado, o que torna ainda mais enigmática a falta de zelo com elas, visto que o maior número de prisões é derivado do tráfico de drogas, e essa parcela representativa, em sua grande maioria vem do envolvimento com o crime através do companheiro, em apreensões nas visitas, que são verdadeiramente constantes. Nesses casos também são formados maiores e mais complexos obstáculos para sua ressocialização, gerando o esquecimento dessas cidadãs e a debilitação da implantação de normas especificas tão necessitadas no complexo feminino. A maternidade nesse âmbito é um assunto delicado, apesar da lei prever o contato do bebê com a mãe nos primeiros 6 meses de vida, seu cumprimento é limitado, principalmente em cadeias superlotadas. Os abusos e maus-tratos para com as detentas grávidas existem e não podem continuar sendo velados. Somente o fato de adaptarem presídios destinados a homens para o uso de mulheres já deixa evidente a existência de um déficit social naquela localidade. Dos tijolos às escovas de dente, esse tipo de instalação não é propícia para a sobrevivência digna de pessoas que precisam de absorventes, sutiãs, calcinhas, itens não cogitados pela massa carcerária masculina. O problema objeto da investigação científica proposta é: quais as dificuldades encontradas pelas mulheres do sistema carcerário brasileiro? A partir das reflexões preliminares sobre o tema, é possível afirmar inicialmente que a falta de voz e constantes violações de direitos básicos, das mulheres no sistema carcerário brasileiro, desencadeiam um ciclo de violência e desigualdade que prejudica a população como um todo. O objetivo geral do trabalho é identificar, examinar e comparar as dificuldades encontradas pelas mulheres pertencentes ao sistema prisional em Belo Horizonte, para constatar quais os reflexos da precariedade do 
Personalidade Acadêmica Homenageada:

Augustus B. Cochran III (Agnes Scott College)

sistema como um todo são encontrados, evidenciando a necessidade de uma maior visibilidade para essa parcela. A pesquisa que se propõe pertence à vertente metodológica jurídico-sociológica. No tocante ao tipo de investigação, foi escolhido, na classificação de Witker (1985) e Gustin (2010), o tipo jurídico-projetivo. O raciocínio desenvolvido na pesquisa será predominantemente dialético. De acordo com a técnica de análise de conteúdo, afirma-se que se trata de uma pesquisa teórica, o que será possível a partir da análise de conteúdo das entrevistas, dos textos doutrinários, normas e demais dados colhidos na pesquisa. A partir do exposto conclui-se que a violação dos direitos das mulheres em situação de cárcere é reflexo da ineficiência da ação estatal, bem como de uma escolha política de tratamento desumano para com as encarceradas.

PALAVRAS-CHAVE: Violação de Direitos; Direitos Humanos; Mulheres; Sistema Carcerário.

\section{REFERÊNCIAS}

BOLDRINI, Angela. Sobre penitenciárias femininas, livro 'Presos que Menstruam' será filme. Disponível em: https://www1.folha.uol.com.br/ilustrada/2015/07/1662690sobre-penitenciarias-femininas-livro-presos-que-menstruam-sera-filme.shtml. Acesso em 10 de maio 2019.

CANTÚ, Mariana Coelho. Condições, processo e experiência do encarceramento feminino: uma pesquisa de campo na penitenciária feminina do paraná. Revista Jurídica - UNICURITIBA-. ISSN 2316-753X. Vol.1, n.38, p.17, 2005. Disponível em: http://revista.unicuritiba.edu.br/index.php/RevJur/article/download/2071/1331. Acesso em: 20 maio 2019.

GUSTIN, Miracy Barbosa de Sousa; DIAS, Maria Tereza Fonseca. (Re)pensando a pesquisa jurídica: teoria e prática. $3^{3}$. ed. Belo Horizonte: Del Rey, 2010.

QUEIROZ, Nana. Presos que menstruam. 9. ed. Rio de Janeiro: Record,2018. 
Personalidade Acadêmica Homenageada:

Augustus B. Cochran III (Agnes Scott College)

SANTOS, R.C.S. Maternidade no cárcere: reflexões sobre o sistema penitenciário feminino. 2011. 121 f. Dissertação (Mestrado em Política Social) - Universidade Federal Fluminense, Escola de Serviço Social, Niterói, 2011.

TALON, Evinis. Execução penal: O direito de visita. http://evinistalon.com/execucaopenal-o-direito-de-visita/ Acesso em: 10 de Mai 2019.

VARELLA, Drauzio. Prisioneiras. São Paulo: Companhia das letras, 2017.

WACQUANT, L. As duas faces do gueto. São Paulo: Boitempo, 2008. 156p.

WITKER, Jorge. Como elaborar una tesis en derecho: pautas metodológicas y técnicas para el estudiante o investigador del derecho. Madrid: Civitas, 1985. 